\title{
Cervical Artery Stenoses in Sickle Cell Disease
}

\author{
Lionel Calviere $^{\mathrm{a}} \quad$ Alain Viguier $^{\mathrm{a}}$ Brigitte Guidolin ${ }^{\mathrm{a}} \quad$ Philippe Tall $^{\mathrm{b}}$ Vincent Larrue $^{\mathrm{a}}$ \\ ${ }^{a}$ Department of Vascular Neurology, Rangueil Hospital, and ${ }^{b}$ Department of Neuroradiology, \\ Purpan and Rangueil Hospitals, Toulouse, France
}

\section{Dear Sir,}

Ischemic stroke is a common complication of sickle cell disease (SCD). Approximately 1 in 10 patients with this disease has a stroke before the age of 20 years, and 20\% have evidence of brain infarction on MRI [1-3]. It is the primary cause of stroke in children [2]. Ischemic stroke in these patients is usually associated with an intracranial internal carotid (IC) fork stenosis or occlusion. Here we report a patient with SCD, ischemic stroke and multiple stenoses of the extracranial carotid and vertebral arteries.

\section{Case Report}

A 19-year-old man was admitted for acute stroke. He was homozygous for the SCD trait. He had not received a regular follow-up but had never had any serious complication of the disease. He used to smoke 10 cigarettes/day. On examination he had dense right hemiplegia and anesthesia, right hemianopsia, global aphasia, somnolence, and gaze deviation to the left. The body temperature was $37^{\circ} \mathrm{C}$. ECG was normal. A computed tomography scan showed early ischemic signs in the left middle cerebral artery (MCA). Carotid ultrasound demonstrated a hypoechoic occlusion of the left carotid bulb. Transcranial Doppler (TCD) showed no flow in the intracranial carotid artery and left MCA. The patient was given intravenous rt-PA $(0.9 \mathrm{mg} / \mathrm{kg})$. A post-treatment TCD showed partial recanalization of the MCA occlusion with the appearance of a blunted flow signal. CRP was decreased to $5 \mathrm{mg} / \mathrm{l}$, cholesterol LDL was $0.8 \mathrm{~g} / \mathrm{l}$, and total hemoglobin $(\mathrm{Hb})$ was $10.3 \mathrm{~g} / \mathrm{dl}$. Hb electrophoresis results were as follows: $\mathrm{SHb}$

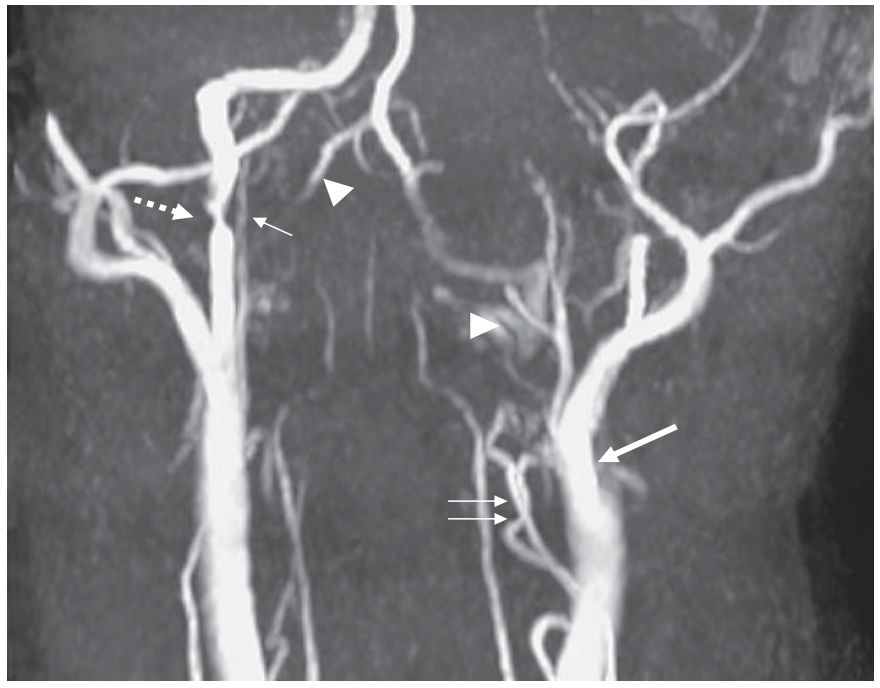

Fig. 1. The cervical time of flight (TOF) showed occlusion of the left IC at the level of the bulb (arrow), the post-bulbar stenosis of right IC (broken arrow) and the occlusion of the vertebral arteries (the right on V4 and the left on V3; arrowhead) with muscular anastomoses (small arrows).

97.8\%; $\mathrm{A} 2 \mathrm{Hb} 2.2 \%$, and $\mathrm{AHb}$ undetectable. Despite thrombolysis, blood transfusion exchanges, and anti-edematous treatment, the patient's condition deteriorated. A decompressive craniectomy was performed on the 4th day. At 6 months, the patient remained hemiparetic and was unable to walk, but his dysphasia had markedly improved. The modified Ranking score was 4 . Screening for thrombophilia (protein C and S, factor VII, antithrombin III and lipoprotein (a) plasma levels, search for antiphospholipid antibodies, factor $\mathrm{V}$
Leyden and prothrombin A 20210 mutations) was negative.

The first magnetic resonance angiography (MRA), performed on day 3, showed occlusion of the left IC artery at the level of the bulb. The left posterior communicating artery partially perfused the distal intracranial carotid artery and the left MCA. There was stenosis of the post-bulbar right IC, occlusion of the vertebral arteries on V3 for the left and V4 for the right, with muscular anastomoses which perfused distally (fig. 1). The posterior intracranial circula-

\section{KARGER}

Fax +4161306 1234 E-Mail karger@karger.ch www.karger.com
(C) 2007 S. Karger AG, Basel 0014-3022/07/0582-0120\$23.50/0

Accessible online at:

www.karger.com/ene
Lionel Calviere

104 avenue de Muret

FR-31300 Toulouse (France)

Tel. +33 610625 533, Fax +33 561779903

E-Mail liocalviere@free.fr 
tion and all right-sided intracranial vessels were angiographically normal. No intramural hematoma was seen in the extracranial arteries on the T1 sequence. A repeat MRA at 6 months showed complete recanalization of the MCA. Occlusion of the left cervical IC and vertebral arteries and stenosis of the extracranial right IC remained unchanged. We did not see any irregular caliber vessels on the circle of Willis.

\section{Discussion}

Ischemic stroke in SCD has long been associated with intracranial T-carotid artery stenosis. Studies with TCD have shown that the prevalence of such stenoses is $50 \%$ in patients with SCD and $80 \%$ in a subgroup with ischemic stroke [4]. Furthermore, the presence of intracranial Tcarotid stenosis as detected by TCD in asymptomatic children is strongly predictive of future ischemic stroke $[3,5,6]$. Most intracranial carotid stenoses develop during the first decade of life [2]. Stenoses affect the supraclinoid carotid and, to a lesser degree, the first segment of MCA and anterior cerebral artery [6-12]. Moyamoya collaterals are associated in approximately $30 \%$ of patients with stroke $[13,14]$. Histological examination of the carotid wall in symptomatic patients shows intimal hyperplasia and fragmentation of the internal elastic membrane with superimposed thrombus. The mechanisms underlying the development of intracranial carotid stenosis may include recurrent endothelial injury by sickled cells, with inflammatory and prothrombotic factor production, high blood flow resulting from chronic anemia, reduction in nitric oxide levels and exposure of the carotid wall to free hemoglobin in the cavernous sinus [3, 15-17].

In the present case, there was no evidence of intracranial artery stenosis. The left MCA was initially occluded, but recanalized after thrombolysis without residual stenosis on control MRA. The posterior circulation perfused the left distal intracranial IC and the MCA. Persistent stenoses and occlusions were exclusively located in the extracranial carotid and vertebral arteries. Spontaneous multiple dissections are unlikely because there was no evidence of intramural hematoma on MRI, and stenoses did not show any trend to- ward regression on the 6-month control MRA. Other classical causes of extracranial carotid and vertebral stenosis/occlusion such as atherosclerosis, arteritis and fibromuscular dysplasia are also unlikely because of the patient's young age, the location of stenoses, and the lack of systemic inflammation or thrombophilia. Thus, the possibility remains that the cervical artery stenoses were secondary to SCD. This would be an exceptional association because we could not find any previous report of cervical artery stenosis in SCD. However, most series have included only children and our patient is a young adult. Furthermore, the present case prompted us to look for extracranial carotid or vertebral stenosis using ultrasound in patients with SCD referred to our neurosonology unit for intracranial artery stenosis screening. We found no cervical artery stenosis in a consecutive series of 15 patients: 7 girls, 8 boys (mean age 17.2, range $8-30$ years; 7 older than 15 years).

In conclusion, the present report suggests that ischemic stroke in SCD may be exceptionally associated with extracranial carotid and vertebral arteriopathy.

\section{References}

1 Powars D, Wilson B, Imbus C, Pegelow C, Allen J: The natural history of stroke in sickle cell disease. Am J Med 1978;65:461-471.

2 Ohene-Frempong K, Weiner SJ, Sleeper LA, Miller ST, Embury S, Moohr JW, Wethers DL, Pegelow CH, Gill FM: Cerebrovascular accidents in sickle cell disease : rates and risk factors. Blood 1998;91:288-294.

3 Hoppe C: Defining stroke risk in children with sickle cell anemia. Br J Haematol 2004; 128:751-766.

4 Gerald B, Sebes JI, Langston JW: Cerebral infarction secondary to sickle cell disease: arteriographic findings. AJR Am J Roentgenol 1980;14:291-295.

5 Adams RJ, McKie VC, Hsu L, Files B, Vichinsky E, Pegelow C, Abboud M, Gallagher D, Kutlar A, Nichols FT, Bonds DR, Brambilla D: Prevention of a first stroke by transfusions in children with sickle cell anemia and abnormal results on transcranial Doppler ultrasonography. N Engl J Med 1998; 339:5-11.

6 Stockman JA, Nigro MA, Mishkin MM, Oski FA: Occlusion of large cerebral vessels in sickle cell anemia. N Engl J Med 1972;287: 846-849.
7 Russell MO, Goldberg HI, Reis L, Friedman S, Slater R, Reivich M, Schwartz E: Transfusion therapy for cerebrovascular abnormalities in sickle cell disease. J Pediatr 1976;88: 382-387.

8 Bernaudin F, Verlhac S, Freard F, RoudotThoraval F, Benkerrou M, Thuret I, Mardini R, Vannier JP, Ploix E, Romero M, CassePerrot C, Helly M, Gillard E, Sebag G, Kchouk H, Pracros JP, Finck B, Dacher JN, Ickowicz V, Raybaud C, Poncet M, Lesprit E, Reinert PH, Brugieres P: Multicenter prospective study of children with sickle cell disease: radiographic and psychometric correlation. J Child Neurol 2000;15:333-343.

9 Zimmerman RA: MRI/MRA evaluation of sickle cell disease of the brain. Pediatr Radiol 2005;35:249-257.

10 Moser FG, Miller ST, Bello JA, Pegelow CH, Zimmerman RA, Wang WC, Ohene-Frempong K, Schwartz A, Vichinsky EP, Gallagher D, Kinney TR: The spectrum of brain MR abnormalities in sickle cell disease: a report from the Cooperative Study of Sickle Cell Disease. AJNR Am J Neuroradiol 1996; 17:965-972.

11 Abboud MR, Cure J, Granger S, Gallagher D, Hsu L, Wang W, Woods G, Berman B, Brambilla D, Pegelow C, Lewin J, Zimmermann RA, Adams RJ; STOP study: Magnetic resonance angiography in children with sickle cell disease and abnormal transcranial Doppler ultrasonography findings enrolled in the STOP study. Blood 2004;103:2822-2826.

12 Steen G, Emudianughe T, Hankins GM, Wynn LW, Wang WC, Xiong X, Helton KJ: Brain imaging findings in pediatric patients with sickle cell disease. Radiology 2003;228: 216-225.

13 Dobson SR, Holden KR, Nietert PJ, Cure JK, Laver JH, Disco D, Abboud MR: Moyamoya syndrome in childhood sickle cell disease: a predictive factor for recurrent cerebrovascular events. Blood 2002;99:3144-3150.

14 Seeler RA, Royal JE, Powe L, Goldberg HR: Moyamoya in children with sickle cell anemia and cerebrovascular occlusion. J Pediatr 1978;93:808-810.

15 Manci EA, Culberson DE, Yang YM, Gardner TM, Powell R, Haynes J Jr, Skah AK, Mankad VN; Investigators of the Cooperative study of Sickle Cell Disease: Causes of death in sickle cell disease: an autopsy study. Br J Haematol 2003;123:359-365.

16 Rothmans M, Fullny KH, Nelson JS: Sickle cell anemia and central nervous system infarction: a neuropathological study. Ann Neurol 1986;20:684-690.

17 Switzer JA, Hess DC, Nichols FT, Adams RJ: Pathophysiology and treatment of stroke in sickle cell disease: present and future. Lancet Neurol 2006;5:501-512. 